\title{
KEPEDULIAN MAHASISWA TERHADAP MASYARAKAT TERDAMPAK WABAH COVID-19 DI DKI JAKARTA DAN D.I. YOGYAKARTA
}

\author{
Edy Purwanto*, Mohammad Farhan Alfathan, Mayang Indriana Embunsari, Nabila Astridayanti, Sonia \\ Aprilya, Edo Daniza Hamzah \\ Teknik Sipil Fakultas Teknik Universitas Sebelas Maret \\ *Email: edypurwanto68@staff.uns.ac.id
}

\begin{abstract}
ABSTRAK
Covid-19 (corona virus disease 2019) merupakan jenis penyakit baru yang disebabkan oleh virus dari golongan SARS-Cov-2. Penularan Covid-19 berlangsung sangat cepat dan menyebar hingga ke berbagai negara di dunia, salah satunya Indonesia yang bermula pada bulan Maret 2020. Jakarta dan Yogyakarta merupakan kota yang memiliki jumlah kasus positif Covid-19 yang cukup tinggi dan termasuk dalam zona merah. Hal tersebut disebabkan oleh kurangnya pemahaman masyarakat terhadap bahaya dari penularan virus Corona. Kebijakan dan peraturan yang selama ini telah diberikan oleh protokoler dan pemerintah masih dianggap enteng dan diabaikan oleh masyarakat. Dengan demikian, Tim KKN Relawan UNS Tanggap Wabah Covid-19 periode Mei - Juni 2020 memutuskan untuk melakukan program kerja dengan tema supporting pemahaman masyarakat terhadap Covid-19, terutama mengenai bahaya virus Corona, cara pencegahannya, serta kebijakan dan peraturan yang harus dipatuhi. Pelaksanaan KKN Relawan UNS Tanggap Wabah Covid-19 berlangsung dengan baik dan sesuai rencana awal. Keberhasilan program kerja karena adanya dukungan dari Ketua RT setempat dan masyarakat. Hasil program kerja KKN yang telah dilaksanakan antara lain yaitu, sosialisasi edukatif mengenai Covid-19 melalui media sosial Instagram dan grup WhatsApp, kegiatan penyaluran masker dan hand sanitizer, serta pembuatan hand sanitizer holder dengan upaya untuk menurunkan tingkat penyebaran Covid-19 di wilayah DKI Jakarta dan Yogyakarta.
\end{abstract}

Kata Kunci : KKN, Covid-19, pemahaman, penecagahan, penularan.

\section{Pendahuluan}

Kuliah Kerja Nyata atau KKN merupakan kegiatan pengabdian kepada masyarakat dalam bentuk kontribusi secara langsung dengan pendekatan lintas keilmuan pada waktu dan daerah tertentu. KKN Relawan UNS Tanggap Wabah Covid-19 adalah suatu kegiatan kontribusi mahasiswa Universitas Sebelas Maret kepada masyarakat di Jakarta dan Yogyakarta dalam menghadapi wabah Covid-19. Warga komplek sebagian besar bekerja sebagai karyawan swasta dan negeri yang mengharuskan untuk tetap melakukan aktivitas di luar rumah. Namun, masih banyak masyarakat yang belum sadar akan pentingnya mematuhi protokol kesehatan yang ada. Padahal, pemerintah dan protokoler telah menetapkan kebijakan serta peraturan untuk mencegah penyebaran Covid-19 yang begitu cepat. Hal tersebut disebabkan karena kurangnya pemahaman masyarakat terhadap bahaya Covid-19 dan cara pencegahannya. Selain itu, masih banyak masyarakat yang percaya terhadap hoax yang beredar di media sosial sehingga keadaan yang sebenarnya atau kebenaran informasi mengenai Covid-19 tidak terungkap dengan jelas. Oleh karena itu, dilaksanakan kegiatan KKN Relawan UNS Tanggap Wabah Covid-19 guna meningkatkan pemahaman 
Jurnal SEMAR Vol. X No. X, hal. $58-69$

ISSN: 2745-4223 | Copyright @ LPPM Universitas Sebelas Maret Homepage: https://jurnal.uns.ac.id/jurnal-semar

masyarakat terhadap Covid-19 dengan harapan dapat memutus rantai penyebaran virus dan mengurangi jumlah kasus positif Covid-19, khususnya di wilayah Jakarta dan Yogyakarta.

\section{Metode Pelaksanaan}

Program KKN Relawan UNS Tanggap Wabah Covid-19 terdiri dari beberapa rangkaian kegiatan. Adapun tahapan dari pelaksanaan kegiatan tersebut, antara lain :

\section{a. Survei Lapangan}

Kegiatan survei lapangan dilakukan sebelum pelaksanaan KKN Relawan UNS Tanggap Wabah Covid19 di Jakarta dan Yogyakarta. Kegiatan survei yang dilakukan berupa perkenalan, diskusi mengenai permasalahan yang dihadapi oleh warga sekitar selama pandemi, penyerahan surat tugas pelaksanaan KKN Relawan UNS Tanggap Wabah Covid-19, serta memohon izin untuk menyelenggarakan program kerja di Jakarta dan Yogyakarta kepada Ketua RT setempat.

\section{b. Koordinasi}

Koordinasi Kuliah Kerja Nyata dilakukan bersama dengan beberapa pihak yang terlibat, antara lain, yaitu :

1. Koordinasi dengan Dosen Koordinator Lapangan.

2. Koordinasi dengan Dosen Pembimbing Lapangan KKN.

3. Koordinasi dengan Ketua RT.009.

\section{c. Persiapan Teknis}

Kegiatan persiapan teknis berupa perizinan untuk melaksanakan Kuliah Kerja Nyata kepada dosen pembimbing melalui Whatsapp, pengarahan dan pelepasan mahasiswa yang mengikuti KKN Relawan UNS Tanggap Wabah Covid-19 oleh Rektor UNS secara daring melalui aplikasi Zoom Meeting, persiapan materi penyuluhan, dan segala hal yang diperlukan dalam pelaksanaan program kerja.

\section{d. Rangkaian Kegiatan}

Rangkaian kegiatan pelaksanaan meliputi dua bidang, yaitu integritas sosial dan produksi. Pelaksanaan program kerja terbagi menjadi tiga macam, yaitu pelaksanaan program utama, pelaksanaan program tambahan, dan pelaksanaan program penunjang.

Pelaksanaan program utama terdiri dari lima program kerja, yaitu:

1. Penyuluhan mengenai pemahaman tentang bahaya, penularan, dan pencegahan Covid-19.

2. Penyuluhan dan pemahaman masyarakat tentang peraturan PSBB

3. Penyuluhan dan pemahaman masyarakat tentang social dan physical distancing.

4. Kegiatan penyaluran masker kain dan hand sanitizer pada beberapa titik wilayah di DKI Jakarta dan Yogyakarta.

5. Kegiatan pembuatan hand sanitizer holder.

Adapun pelaksanaan program tambahan antara lain, yaitu:

1. Pencerdasan terkait isu-isu mengenai Covid-19 yang beredar di masyarakat.

2. Pencerdasan informasi terkini dalam dunia internasional akibat dari pandemi Covid-19.

3. Pencerdasan tentang teori konspirasi Covid-19 yang beredar di Indonesia.

4. Pemberian informasi mengenai dampak positif adanya virus Corona.

Sedangkan untuk pelaksanaan program penunjang antara lain, yaitu:

1. Giveaway dana virtual yang bekerja sama dengan start-up lokal di Jakarta.

2. Kegiatan update perkembangan jumlah kasus Covid-19 di Indonesia melalui fitur story Instagram @ covidity.uns. 


\section{Hasil dan Pembahasan}

\section{A. Program Utama}

Program utama dari KKN Relawan UNS Tanggap Wabah Covid-19 terdiri dari kegiatan sosialisasi edukatif yang dilakukan melalui media sosial, penyaluran masker kain dan hand sanitizer, serta pembuatan hand sanitizer holder. Media sosial yang digunakan adalah Instagram, yaitu @covidity.uns dan penyuluhan Covid-19 kepada warga RT.009/RW.009, Kelurahan Malaka Sari melalui grup WhatsApp komplek.

\section{Penyuluhan mengenai pemahaman tentang bahaya, penularan, dan pencegahan dari Covid-19}

Pada masa pandemi seperti sekarang ini, masyarakat diharuskan untuk hidup berdampingan langsung dengan virus Corona yang penyebarannya sangat cepat. Dengan demikian, masyarakat perlu memahami secara benar tentang bahaya virus Corona dan cara pencegahannya. Oleh karena itu, pada Minggu, 14 Juni 2020 kami melakukan penyuluhan tersebut dengan media poster melalui Instagram dan grup WhatsApp. Penyuluhan mengenai bahaya dan pencegahan virus Corona ini bertujuan untuk meningkatkan kesadaran dan pemahaman masyarakat akan pentingnya pengetahuan Covid-19, khususnya dalam hal bahaya, penularan, dan pencegahan virus tersebut.
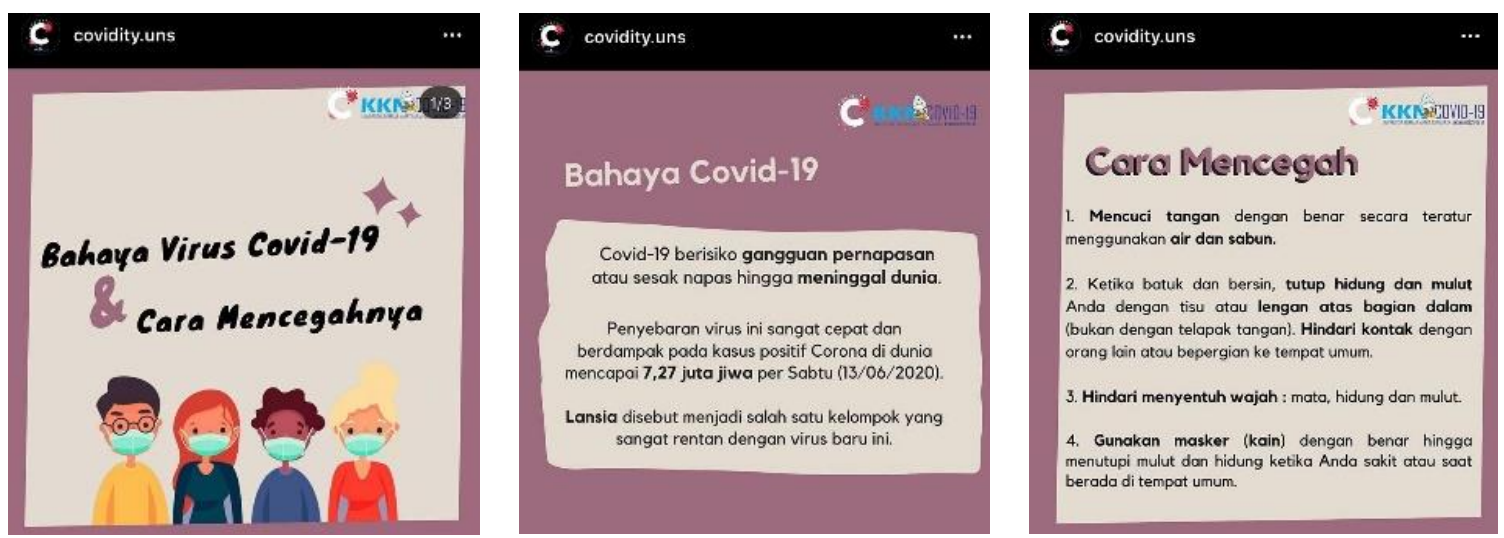

Gambar 1. Penyuluhan Mengenai Bahaya, Penularan, dan Pencegahan Covid-19

(Sumber : Dokumentasi KKN Pondok Kelapa Mei - Juni 2020)

Hasil dari pelaksanaan kegiatan penyuluhan ini mendapat respon baik dari pengguna aktif Instagram dan member grup WhatsApp. Kegiatan ini telah terlaksana dengan baik dan berjalan lancar, sedangkan faktor penghambat adalah penyuluhan ini hanya dilihat oleh followers dan pengguna aktif media sosial karena tidak semua orang memiliki akun Instagram. Dengan begitu, kami mengupayakan penyebaran poster tersebut dengan membagikannya pada akun Instagram pribadi dan kepada teman-teman sehingga target penyuluhan dapat dilihat oleh pengguna Instagram sebanyak mungkin. Hasil yang dicapai dari kegiatan ini adalah masyarakat sudah menerapkan dan memahami bahaya, penularan, dan pencegahan Covid-19 sehingga penyebaran virus dapat ditekan sampai pandemi berakhir.

\section{Penyuluhan dan pemahaman masyarakat tentang peraturan PSBB}

PSBB adalah singkatan dari Pembatasan Sosial Berskala Besar, peraturan yang diterbitkan oleh pemerintah dalam rangka menangani percepatan penyebaran Covid-19 di berbagai daerah. Kriteria wilayah yang wajib menerapkan PSBB adalah memiliki peningkatan jumlah kasus dan kematian akibat Covid-19 secara signifikan. Wilayah DKI Jakarta menjadi salah satu daerah zona merah, dimana terjadi 
lonjakan penambahan kasus positif Covid-19 yang cukup tinggi. Pada Kamis, 11 Juni 2020 kami melakukan penyuluhan tentang peraturan PSBB di Instagram dan grup WhatsApp. Dengan dilaksanakannya penyuluhan ini, diharapkan masyarakat dapat mematuhi peraturan PSBB sebagaimana mestinya.

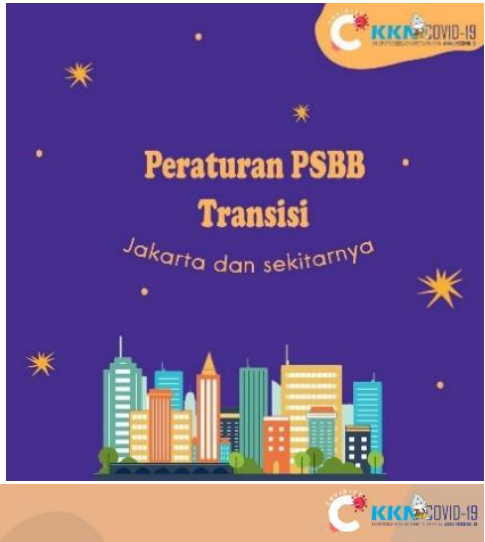

Tempat Ibadah
mulai dibuka perlahan!

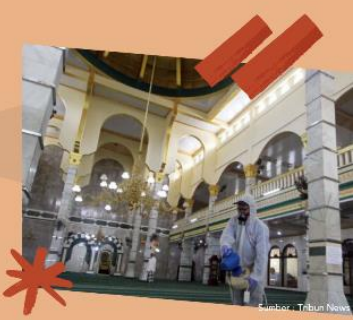

Gambar 2. Penyuluhan Mengenai Peraturan PSBB

(Sumber : Dokumen KKN Pondok Kelapa Mei - Juni 2020)
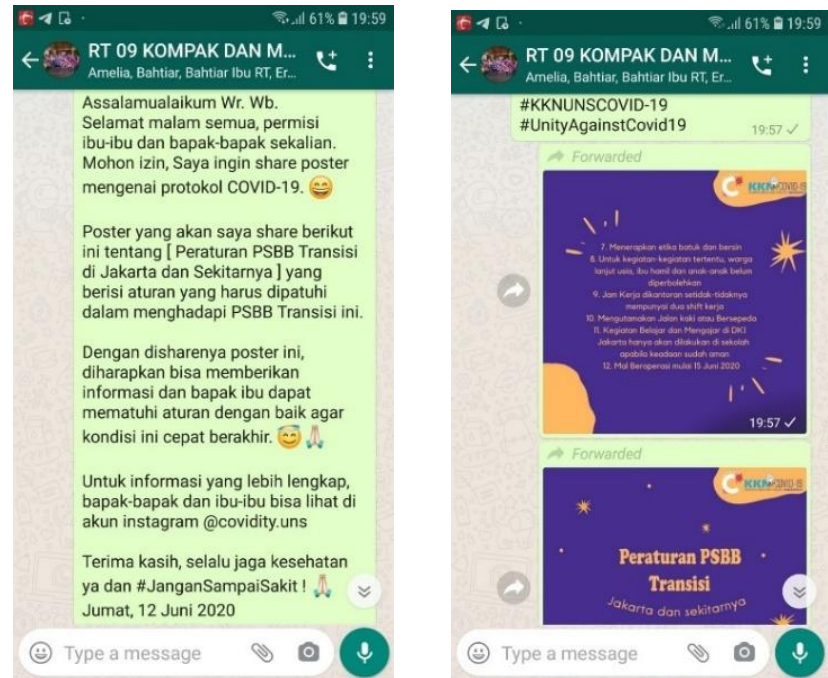

Gambar 3. Penyuluhan Mengenai Peraturan PSBB Melalui Grup WhatsApp

(Sumber : Dokumen KKN Pondok Kelapa Mei - Juni 2020) 
Kegiatan ini mendapat dukungan penuh dari pengguna aktif Instagram dan warga RT.009 / RW.009 sehingga dapat berjalan dengan lancar dan sesuai rencana awal. Faktor penghambat dari kegiatan ini adalah penyuluhan yang tidak tersalurkan secara merata kepada semua orang karena keterbatasan pengguna Instagram, sedangkan untuk penyuluhan di grup WhatsApp telah dilihat sebanyak 79 orang. Hasil yang dicapai dari penyuluhan peraturan PSBB adalah masyarakat sudah mulai mematuhi dan menerapkan kebijakan yang ditetapkan pemerintah selama pandemi.

\section{Penyuluhan dan pemahaman masyarakat tentang social dan physical distancing.}

Selama berlangsungnya pandemi, banyak istilah-istilah baru yang banyak masyarakat belum memahaminya. Contohnya, seperti istilah dari social distancing, physical distancing, isolasi, dan lain-lain. Dengan demikian, kami bermaksud untuk memberikan informasi mengenai istilah yang ada pada masa wabah Covid-19 dengan tujuan agar masyarakat dapat memahami hal-hal terkait Covid-19 sehingga dapat menerapkan protokol kesehatan dengan baik dan benar. Pada Sabtu, 13 Juni 2020 kami melaksanakan penyuluhan tentang social dan physical distancing dengan media poster melalui Instagram dan grup WhatsApp. Dengan dilaksanakannya penyuluhan ini, diharapkan masyarakat dapat mengetahui istilah dari social distancing, physical distancing, isolasi, dan karantina. Kegiatan ini mendapat respon baik dari pengguna aktif Instagram dan member grup WhatsApp. Hasil yang dicapai dari kegiatan ini adalah masyarakat memahami perbedaan social distancing dengan physical distancing, istilah lain seperti isolasi dan karantina, serta memahami pentingnya social dan physical distancing selama wabah virus Corona.
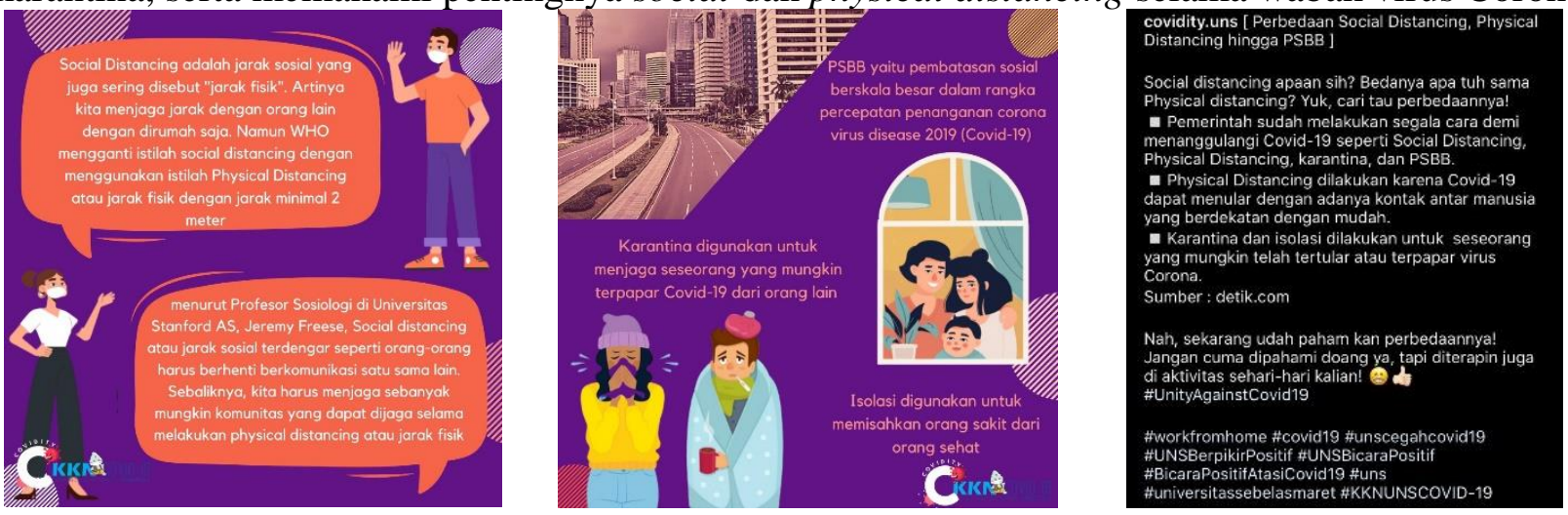

Gambar 4. Penyuluhan Mengenai Social dan Physical Distancing

(Sumber : Dokumentasi KKN Pondok Kelapa Mei - Juni 2020)

\section{Kegiatan penyaluran masker kain dan hand sanitizer}

Penularan virus Corona menjadi penularan penyakit yang sangat cepat dibandingkan dengan penyakit lainnya. Kontak dekat dengan seseorang yang tanpa diketahui mengeluarkan air liur atau sekresi pernapasan dengan droplet yang berukuran sangat kecil dapat berpotensi menularkan virus. Oleh karena itu, WHO memberlakukan imbauan untuk selalu menjaga jarak, minimal sejauh dua meter. Cara lain yang paling efektif dan ampuh dalam mencegah penyebaran Covid-19 adalah dengan menggunaan masker dan hand sanitizer. Masker mampu menghalangi droplet yang keluar sehingga tidak menyebarkan virus, sedangkan orang yang sehat akan selalu terlindungi. Begitu juga dengan hand sanitizer yang menjadi alternatif untuk membersihkan tangan jika tidak ada air dan sabun. Namun, masih banyak masyarakat yang belum sadar akan pentingnya penggunaan masker dan hand sanitizer. Dengan demikian, kami memutuskan untuk melakukan penyaluran masker kain dan hand sanitizer kepada masyarakat di beberapa 
titik lokasi DKI Jakarta dan Yogyakarta. Penyaluran dengan total sejumlah 150 paket masker kain dan 100 botol hand sanitizer dibagikan serentak di tiga titik lokasi yang berbeda, yaitu:

- Kelurahan Ulujami, Jakarta Selatan pada Sabtu, 20 Juni 2020

- Kecamatan Duren Sawit, Jakarta Timur pada Minggu, 21 Juni 2020

- Kecamatan Pakualaman, Yogyakarta pada Minggu, 21 Juni 2020
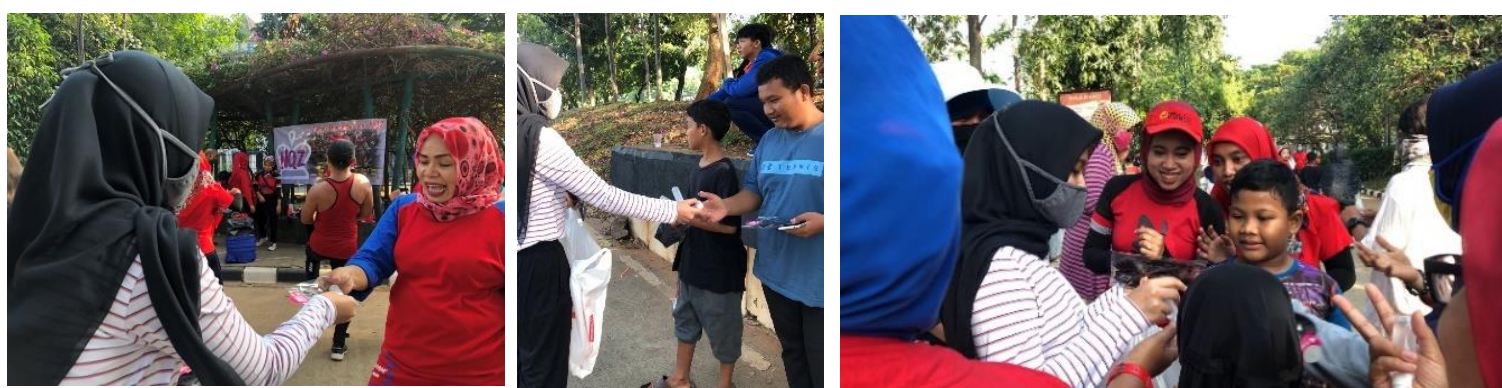

Gambar 5. Pelaksanaan Penyaluran Masker dan Hand Sanitizer di Duren Sawit, Jakarta Timur (Sumber : Dokumentasi KKN Pondok Kelapa Mei - Juni 2020)
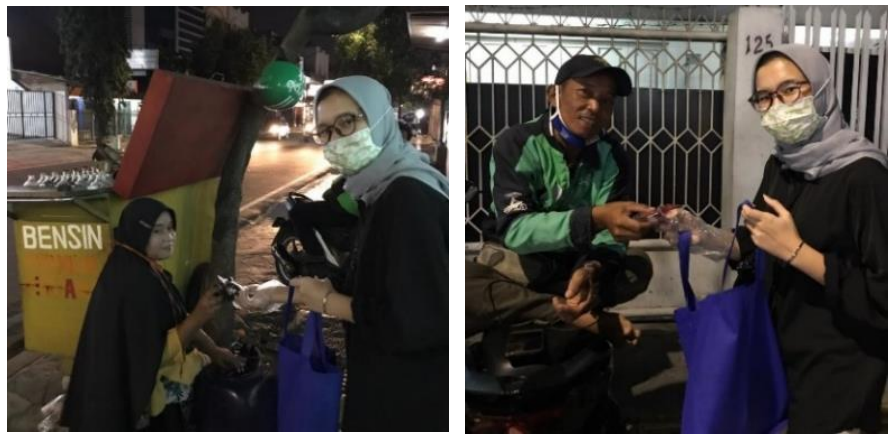

Gambar 6. Pelaksanaan Penyaluran Masker dan Hand Sanitizer di Ulujami, Jakarta Selatan (Sumber : Dokumentasi KKN Pondok Kelapa Mei - Juni 2020)
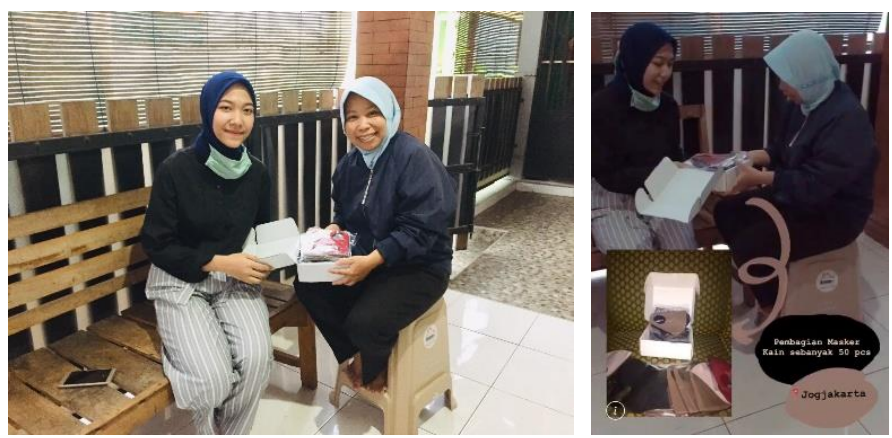

Gambar 7. Pelaksanaan Penyaluran Masker dan Hand Sanitizer di Pakualaman, Yogyakarta (Sumber : Dokumentasi KKN Pondok Kelapa Mei - Juni 2020)

Hasil dari kegiatan ini diharapkan masyarakat minimal memiliki satu buah masker dan hand sanitizer, serta sadar akan pentingnya penggunaan masker dan menjaga kebersihan tangan di tempat umum sehingga dapat menekan penyebaran kasus Covid-19, terutama pada wilayah zona merah. Pelaksanaan penyaluran masker dan hand sanitizer berjalan dengan lancar dan mendapat dukungan penuh dari masyarakat dan Ketua RT setempat. Namun, kondisi saat pembagian masker dan hand sanitizer di wilayah Duren Sawit, 
Jakarta Timur kurang kondusif karena banyak orang yang berebut sedangkan jumlah paket yang dibagikan tidak mencukupi jumlah masyarakat karena keterbatasan anggaran.

\section{Kegiatan pembuatan hand sanitizer holder}

Pemberlakuan physical distancing menjadi salah satu protokol kesehatan yang sudah seharusnya dipatuhi oleh seluruh masyarakat untuk memutus rantai penyebaran Covid-19. Walaupun sudah menerapkan physical distancing, masyarakat tetap harus sadar bahwa virus Corona bukan hanya tertular melalui jarak antar manusia yang dekat, melainkan juga droplet dari virus tersebut yang menempel di berbagai media yang tidak dapat dihindari, salah satunya adalah kontak pada alat hand sanitizer yang tersedia di tempat umum. Oleh karena itu, kami bermaksud untuk mengurangi adanya kontak fisik pada alat hand sanitizer di tempat umum dengan cara membuat hand sanitizer holder. Kegiatan pembuatan hand sanitizer holder dilaksanakan di Kebon Jeruk pada hari Minggu, 21 Juni 2020. Cara penggunaan dari hand sanitizer holder yaitu dengan menginjak bagian bawah stand sehingga cairan hand sanitizer dapat keluar secara otomatis. Harapan dari terlaksananya kegiatan ini adalah untuk mengurangi kontak fisik penggunaan hand sanitizer di tempat umum sehingga penerapan physical distancing yang dirancang oleh pemerintah dapat terlaksana dengan maksimal. Hand sanitizer holder diletakkan di Pos Kamling RT.004/RW.011, Kebon Jeruk, Jakarta Barat agar dapat digunakan bersama oleh warga sekitar. Hasil dari kegiatan ini berupa hand sanitizer holder yang dapat berfungsi dengan baik dan antusias warga dalam menggunakan alat tersebut sangat tinggi. Hand sanitizer holder digunakan oleh warga komplek dan ojek online yang berada di area pos kamling. Hambatan dari kegiatan ini adalah kurangnya pengetahuan kami mengenai teknis pembuatan alat tersebut sehingga proses pembuatan alat membutuhkan waktu yang cukup lama.
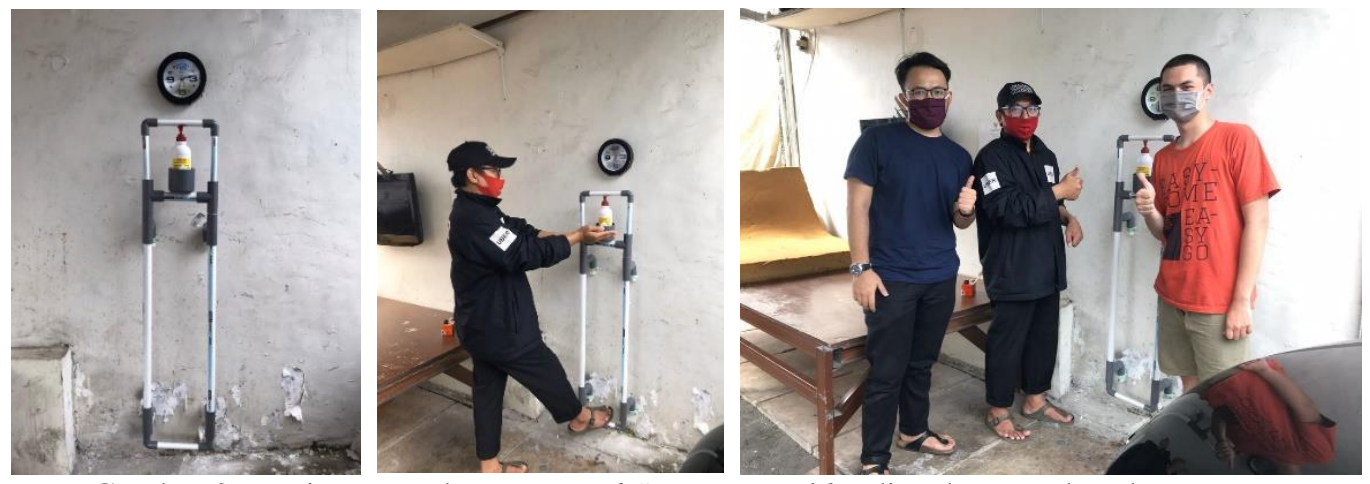

Gambar 8. Kegiatan Pembuatan Hand Sanitizer Holder di Kebon Jeruk, Jakarta Barat

(Sumber : Dokumentasi KKN Pondok Kelapa Mei - Juni 2020)

\section{B. Program Tambahan}

\section{Pencerdasan terkait isu-isu mengenai Covid-19 yang beredar di masyarakat}

Wabah Covid-19 yang terjadi di Indonesia menimbulkan banyak informasi tentang Covid-19 yang beredar luas tanpa diketahui kebenaran yang pasti. Hal tersebut menyebabkan kekhawatiran dan rasa takut dalam benak masyarakat Indonesia. Untuk mengatasi kekhawatiran itu, kami bermaksud untuk mengungkap fakta dari isu-isu Covid-19 yang beredar di masyarakat, terutama dalam media sosial. Kami melakukan research terhadap isu-isu Covid-19 yang beredar luas dan mengungkap apakah isu tersebut merupakan fakta atau hoax. Kegiatan ini bertujuan agar tidak ada informasi hoax yang merebak sehingga masyarakat tetap tenang dan selalu waspada selama pandemi berlangsung. Program ini dilaksanakan melalui media poster yang dipublikasikan di Instagram @covidity.uns dan grup WhatsApp. Kegiatan ini mendapat 
respon yang baik dari pengguna aktif Instagram dan member grup WhatsApp, dengan kendala tidak semua orang dapat turut berpartisipasi karena tidak semua pribadi menggunakan Instagram sebagai media sosial. Hasil yang dicapai dari kegiatan ini adalah masyarakat dapat memahami serta mampu membedakan antara informasi yang merupakan fakta atau hoax.

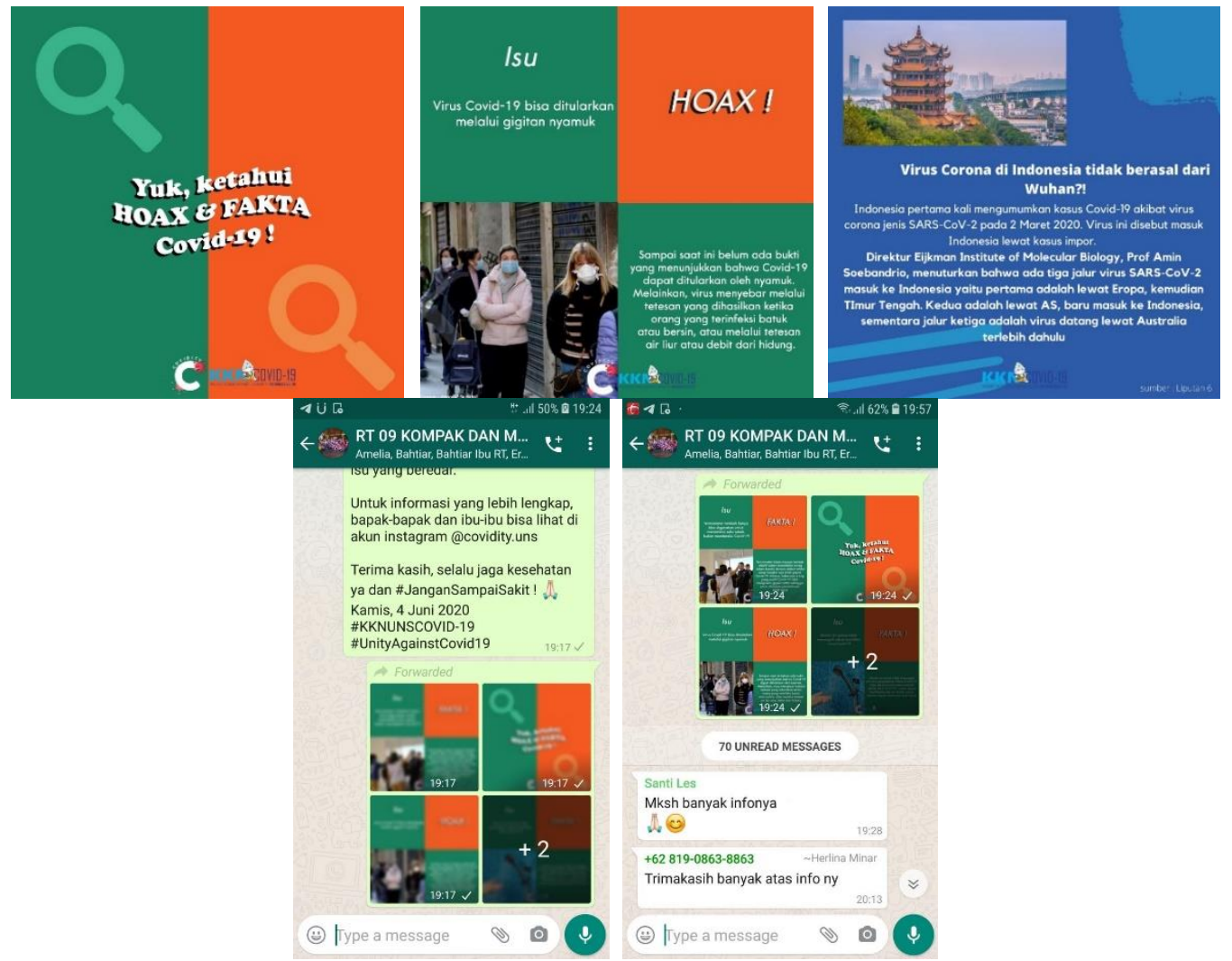

Gambar 9. Pencerdasan Mengenai Isu-Isu Covid-19

(Sumber : Dokumentasi KKN Pondok Kelapa Mei - Juni 2020)

\section{Pencerdasan informasi terkini dalam dunia internasional akibat dari pandemi Covid-19}

Pandemi Covid-19 tidak hanya terjadi di Indonesia, melainkan sudah menyebar hampir ke seluruh belahan dunia. Banyak tragedi di berbagai negara yang muncul selama masa pandemi ini. Sayangnya, masih banyak masyarakat Indonesia yang belum mengetahui hal-hal yang terjadi pada dunia internasional. Padahal, informasi mengenai negara lain dalam menghadapi wabah Covid-19 sangat penting untuk diketahui agar wawasan masyarakat lebih terbuka dan up-to-date terhadap kondisi dunia saat ini. Dengan demikian, kami melakukan kegiatan ini dengan maksud untuk meningkatkan awareness masyarakat domestik terhadap kondisi internasional di berbagai negara dalam menghadapi virus Corona. 

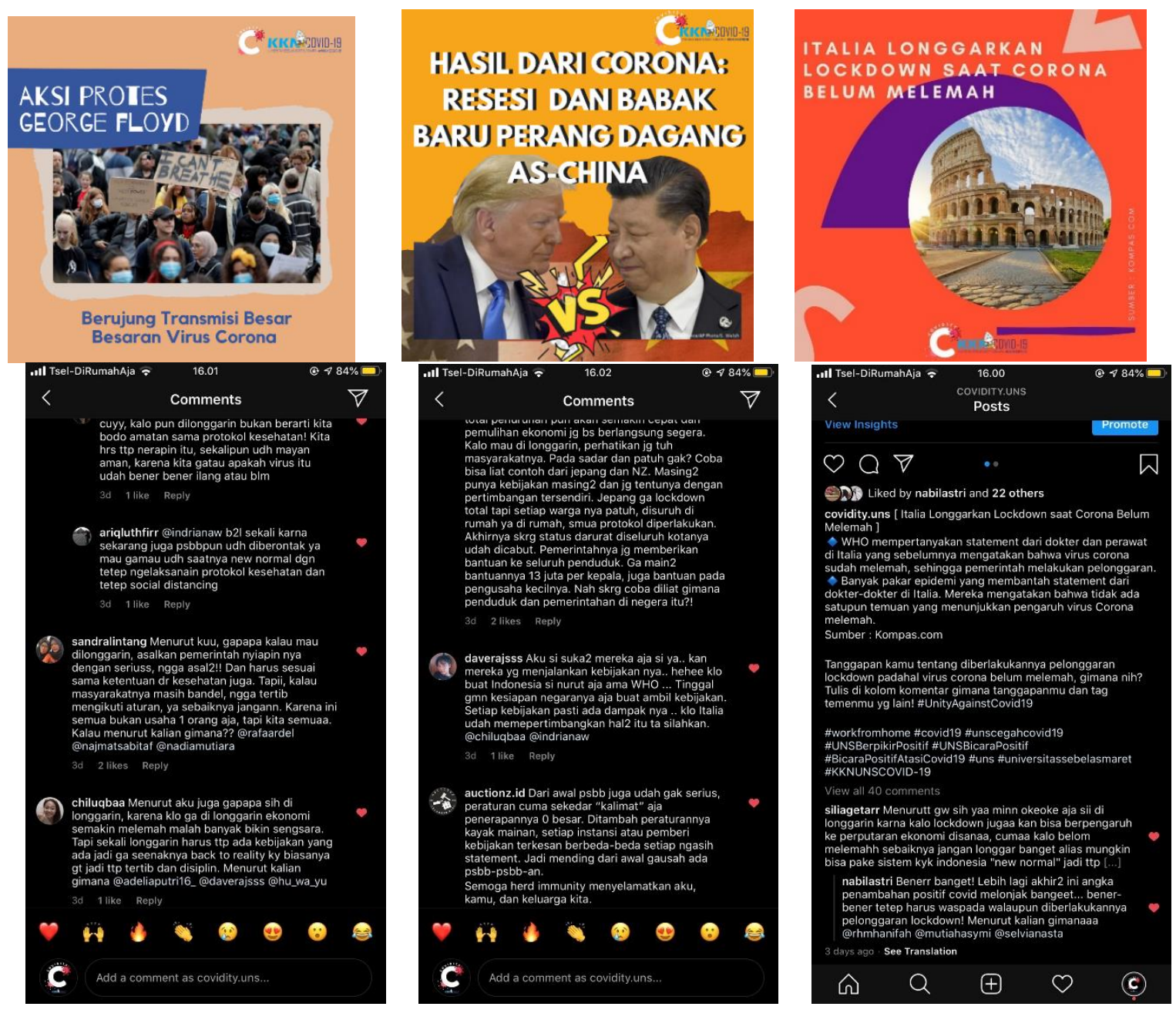

Gambar 10. Pencerdasan Mengenai Dunia Internasional Dalam Menghadapi Covid-19

(Sumber : Dokumentasi KKN Pondok Kelapa Mei - Juni 2020)

Kegiatan pencerdasan informasi mengenai dunia internasional dalam menghadapi pandemi dilakukan dengan media poster yang di-posting melalui Instagram secara berkala. Berikut adalah bahasan yang telah kami publikasikan di Instagram antara lain, yaitu:

- New normal yang gagal di Korea Selatan.

- Aksi protes George Floyd yang berujung transmisi besar-besaran virus Corona.

- Amerika Serikat akan uji vaksin Corona pada 30.000 orang.

- Italia longgarkan lockdown saat corona belum melemah.

- Hasil dari Corona: resesi dan babak baru perang dagang AS-China.

- Virus Corona tidak akan membahayakan eksistensi umat muslim di dunia

Kegiatan ini berjalan dengan lancar dan mendapat respon yang sangat baik dari pengguna aktif Instagram. Banyak pengguna aktif Instagram yang antusias dan tertarik dengan pembahasan tentang Covid-19 dalam dunia internasional, hal ini dapat dibuktikan dengan adanya 40 respon pengguna Instagram yang beropini di kolom komentar sehingga kegiatan ini berlangsung komunikasi secara dua arah. Hasil yang dicapai dari kegiatan ini adalah masyarakat dapat memahami dan memiliki wawasan yang lebih luas mengenai kondisi internasional pada masa pandemi. 


\section{Pencerdasan tentang teori konspirasi Covid-19 yang beredar di Indonesia}

Salah satu penyebab kebijakan atau peraturan pemerintah tentang Covid-19 yang tidak terealisasi dengan baik dikarenakan adanya opini masyarakat mengenai kebenaran virus Corona. Banyak tokoh publik yang berpendapat mengenai Covid-19 yang membuat masyarakat menjadi bingung karena munculnya teori konspirasi dari beberapa tokoh tersebut. Ada masyarakat yang bijak dalam menangkis teori konspirasi tersebut dan tetap menjalankan protokol kesehatan, tetapi di sisi lain banyak juga masyarakat yang percaya akan teori konspirasi tersebut sehingga mulai mengabaikan peraturan dan protokol kesehatan. Oleh karena itu, kami mencoba untuk memberikan kebenaran dan penjelasan mengenai teori konspirasi Covid-19 yang selama ini beredar di masyarakat. Kegiatan ini dilakukan dengan media poster yang di-posting melalui Instagram@covidity.uns secara berkala.
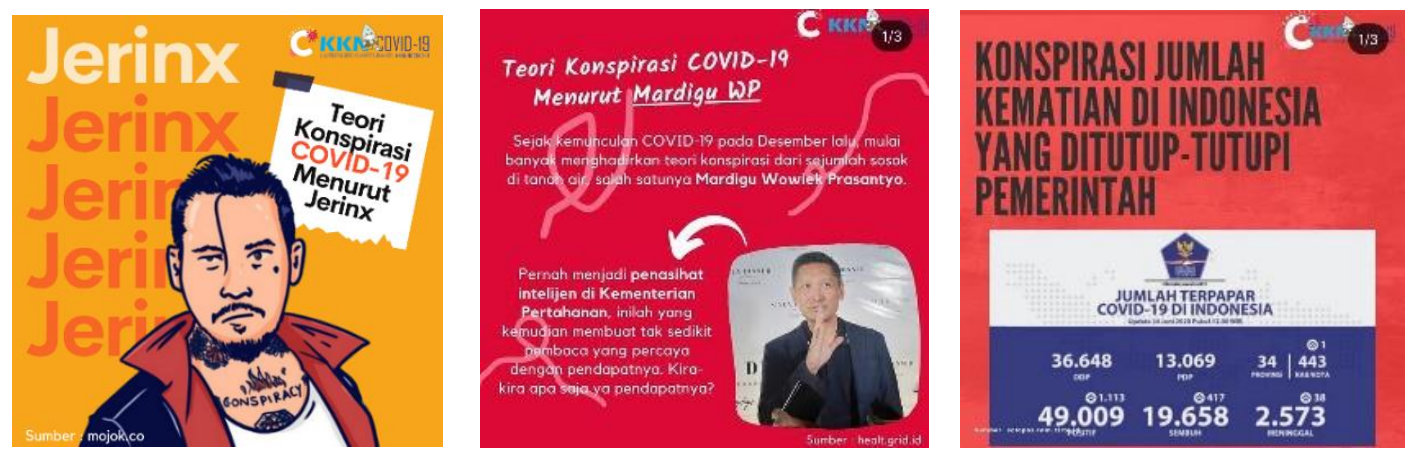

Gambar 11. Pencerdasan Mengenai Dunia Internasional Dalam Menghadapi Covid-19

(Sumber : Dokumentasi KKN Pondok Kelapa Mei - Juni 2020)

Kegiatan ini mendapat respon yang baik dari pengguna aktif Instagram, dengan kendala tidak semua orang turut berpartisipasi karena keterbatasan penggunaan media sosial. Hasil yang dicapai dari kegiatan ini adalah masyarakat dapat memahami dan mengolah setiap berita atau teori konspirasi yang beredar sehingga kedepannya tidak terjadi lagi kesalahpahaman.

\section{Pemberian informasi mengenai dampak positif adanya virus Corona}

Hadirnya virus Corona dalam kehidupan sangat merugikan banyak orang, baik dari aspek kesehatan, perekonomian, terhambatnya proses pendidikan di sekolah maupun perguruan tinggi, dan lain-lain. Namun, keadaan seperti ini tidak dapat dihindari karena adanya Covid-19 adalah kehendak dari Tuhan. Oleh karena itu, sebagai manusia kita harus bisa menempatkan diri pada kondisi apapun, salah satunya dengan mengambil sisi positif dari wabah Covid-19. Secara tidak langsung, ada banyak hikmah dan halhal positif yang dapat kita lakukan selama pandemi ini. Dengan demikian, kami bermaksud untuk membagikan dampak positif dari adanya virus Corona agar masyarakat tetap bersyukur dan produktif. Kegiatan ini dilaksanakan pada hari Selasa, 16 Juni 2020 dengan media poster di Instagram. Hal ini mendapat respon yang baik dari pengguna aktif Instagram. Hasil yang dicapai dari kegiatan ini adalah masyarakat mulai bersyukur dan dapat mengambil sisi positif dari pandemi ini. 

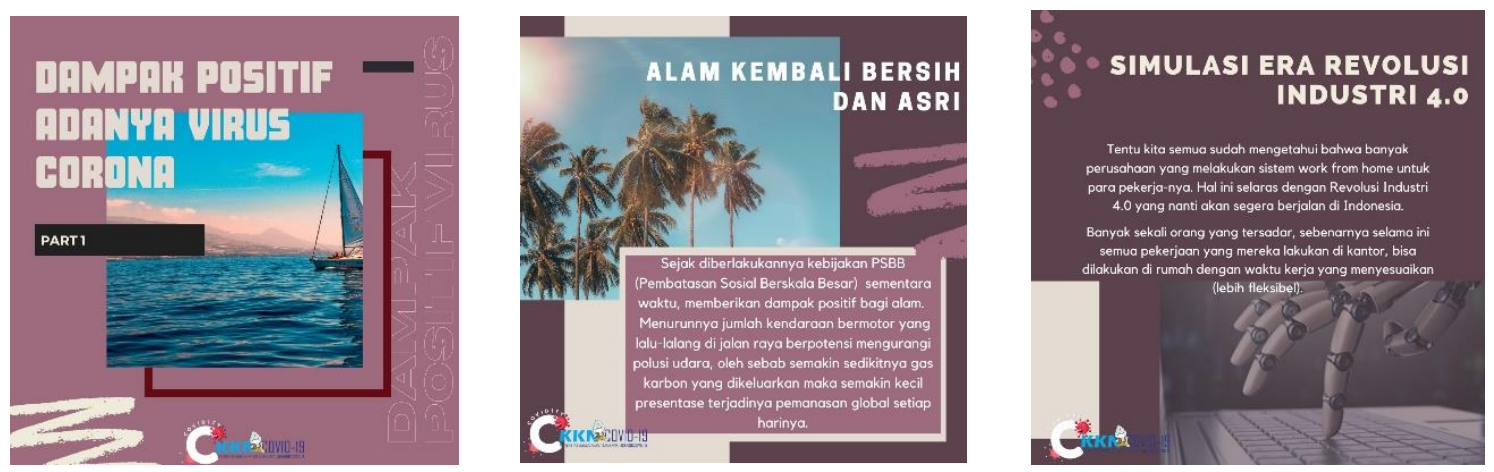

Gambar 12. Pemberian Informasi Mengenai Dampak Positif Adanya Virus Corona

(Sumber : Dokumentasi KKN Pondok Kelapa Mei - Juni 2020)

\section{Program Penunjang}

\section{Giveaway dana virtual yang bekerja sama dengan start-up lokal di Jakarta}

Giveaway merupakan salah satu program kerja penunjang yang bertujuan untuk mencari pengguna aktif Instagram sebanyak-banyaknya agar akun @ covidity.uns diketahui khalayak luas sehingga program kerja yang sebagian besar dilakukan di Instagram mendapatkan engagement yang tinggi dan informasi atau penyuluhan yang diberikan dapat tersalurkan kepada semua kalangan pengguna Instagram. Kami bekerja sama dengan start-up lokal di Jakarta, @ auctionz.id, untuk mencari followers sebanyak mungkin sehingga sosialisasi edukatif di Instagram dapat diketahui lebih banyak orang.
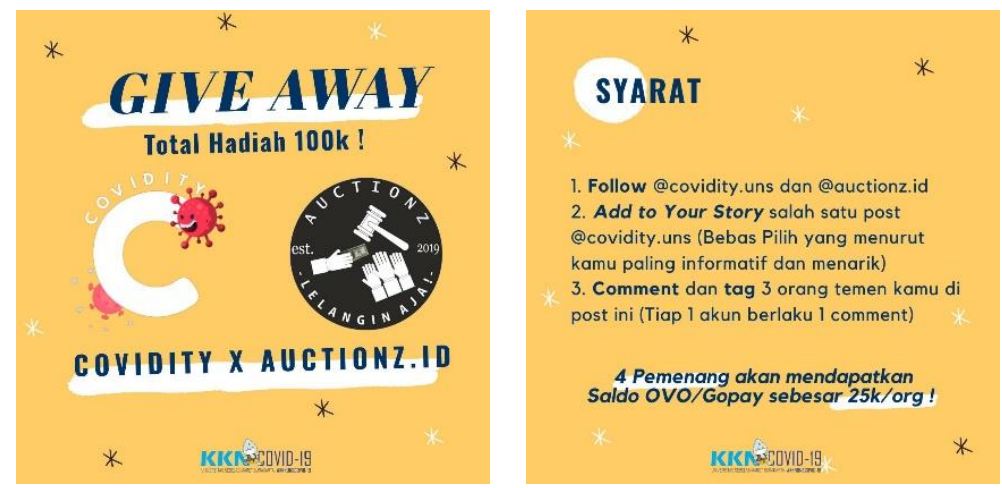

Gambar 13. Giveaway yang bekerja sama dengan start-up lokal di Jakarta

(Sumber : Dokumentasi KKN Pondok Kelapa Mei - Juni 2020)

Kegiatan ini mendapat respon yang baik dari pengguna Instagram, yang dibuktikan dengan 32 akun Instagram yang mengikuti giveaway ini dan bertambahnya jumlah followers @ covidity.uns yang cukup signifikan. Hasil yang dicapai dari kegiatan ini adalah semakin banyak pengguna Instagram yang mengetahui akun@covidity.uns, serta turut berpartisipasi pada program kerja KKN Relawan UNS Tanggap Wabah Covid-19 lainnya.

\section{Kegiatan update perkembangan jumlah kasus Covid-19 di Indonesia}

Program penunjang lainnya adalah melakukan update terhadap perkembangan jumlah kasus Covid-19 di Indonesia. Kegiatan ini dilaksanakan setiap hari melalui fitur story di Instagram. Dengan dilakukannya kegiatan tersebut, diharapkan masyarakat selalu aware dan waspada terhadap Covid-19 yang sampai sekarang masih belum ditemukan vaksinnya. Kegiatan ini mendapat respon yang baik dari masyarakat. 
Hasil yang dicapai dari kegiatan ini adalah masyarakat dapat memantau perkembangan jumlah kasus di Indonesia dengan mudah.

\section{Kesimpulan}

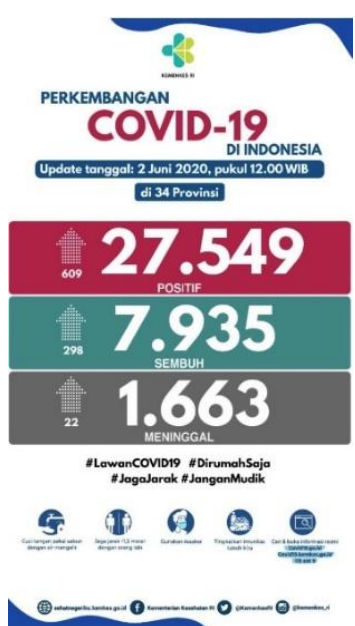

Gambar 14. Update Perkembangan Covid-19 di Indonesia (Sumber : Dokumentasi KKN Pondok Kelapa Mei - Juni 2020)

Dari beberapa program kerja yang telah terlaksana, pemahaman masyarakat mengenai Covid-19 sudah mulai meningkat. Masyarakat mulai paham akan pentingnya menggunakan masker dan menjaga kebersihan tangan, bahaya, penuaran, dan cara pencegahan virus Corona, serta pembahasan lainnya yang dibagikan melalui Instagram dan grup WhatsApp. Hasil capaian ini sesuai dengan yang diharapkan, dan khususnya kasus positif Covid-19 di wilayah Jakarta dan Yogyakarta tidak mengalami kenaikan yang begitu tinggi.

\section{Ucapan Terima Kasih}

Penulis mengucapkan terima kasih yang sebesar-besarnya kepada LPPM dan UPKKN UNS, masyarakat sekitar komplek, Ketua RT, serta saudari Mayang Indriana Embunsari dengan NIM. I0117080; Mohammad Farhan Alfathan dengan NIM. I0117085; Nabila Astridayanti dengan NIM. I0117095; Sonia Aprilya dengan NIM. I0117128; Edo Daniza Hamzah dengan NIM. I0417029 selaku mahasiswa peserta KKN Relawan UNS Tanggap Wabah Covid-19 periode Mei - Juni 2020 di Jakarta dan Yogyakarta.

\section{Daftar Pustaka}

Pemerintah Provinsi DKI Jakarta. 2020. Tanggap Darurat Corona Virus Provinsi DKI Jakarta. https://dinkes.jakarta.go.id/. Diakses pada 5 Juli 2020 pada pukul 19.00 WIB.

Rothan, H.A. and S.N. Byrareddy. 2020. The Epidemiology and Pathogenesis of Coronavirus Disease (COVID-19) Outbreak. Journal of Autoimmunity. Vol. 109: 1-4.

Pemerintah Provinsi DKI Jakarta. 2020. Data Pantauan COVID-19 Jakarta. https://corona.jakarta.go.id/id. Diakses pada 8 Juli 2020 pada pukul 14.00 WIB.

Dinas Kesehatan DIY. 2020. Data Terkait COVID-19 di D.I. Yogyakarta. https://corona.jogjaprov.go.id/data-statistik. Diakses pada 9 Juli 2020 pada pukul 16.00 WIB. 